\title{
An Evaluation of the Influence of Information Sources on Adoption of Agroforestry Practices in Kajiado Central Sub-County, Kenya
}

\author{
Stephen Gitonga ${ }^{1, *}$, Wangia S. M. Mukoya ${ }^{2}$ \\ ${ }^{1}$ Kenya Forestry Research Institute, Kenya \\ ${ }^{2}$ Department of Agricultural Economics, University of Nairobi, Kenya
}

Copyright $\bigcirc 2016$ by authors, all rights reserved. Authors agree that this article remains permanently open access under the terms of the Creative Commons Attribution License 4.0 International License

\begin{abstract}
Access to information on agroforestry is a key transformer to agricultural productivity. This study was undertaken to find out Information Communication and Technologies (ICTs) sources and factors influencing access and use of these information sources by smallholder agroforestry farmers in Kajiado Central, sub-County in Kenya. A survey of 67 respondents was analyzed using Chi-square at 0.05 levels of significance to determine relationship between socio-economic characteristics of households and access to agroforestry information sources. The results showed $53.7 \%$ of the farming households used face to face communication namely; neighbours and friends, extension agents and group meeting, while $34.1 \%$ actively used ICTs information sources namely; radio, television, telephone and internet; and $28.8 \%$ used demonstrations and publicity events to disseminate (one way) or share (receive and send feedback) information on agroforestry practices. Land size, secured land tenure, education level, monthly income and distance to the shopping centre were socio-economic factors found statistically significantly difference $(p<0.05)$ and positively influencing farmers' access to sources of agroforestry information. The study recommends policy makers, planners and implementers to empower farming households through capacity building, incorporating ICT devices, supporting farmers to farmers meetings to promote agroforestry practices in Kenya.
\end{abstract}

Keywords Agroforestry, Information Sources, Socio-economic Factors

\section{Introduction}

Globally, farmers constantly seek agricultural information to increase production and overcome challenges of reducing land productivity potential. In Kenya, research institutions, universities, agricultural based firms and financial institutions are core agricultural information sources available to farmers through various other information platforms that integrate ICT devices [1]. These institutions are essential knowledge base as they hold diverse agroforestry information and research findings as well as relevant skills developed to improve agricultural and industrial practices.

In the past three decades or so, agroforestry practices [2], was promoted through pilot projects targeting communities in Kajiado sub-County, Kenya to embrace sustainable land use systems [3]. On farm tree planting in form of woodlots, silvi-pasture and apiculture with trees, wind breaks, boundary planting, fodder banks, and fruit orchards are some of the agroforestry farming systems adopted in the area of this study. These practices, plotted by either the government ministries or private sector are either modification of an existing practice more novel to farmers. The aim is to conserve the drylands through increased vegetation cover, provision of fodder [4] and wood fuel, soil protection, food security as well as lessen negative effects of climate change $[5,6]$.

Adoption of agroforestry practices in the recent years made tremendous strides though many of the success stories appear to be confined to small areas. This infers that in terms of its wider application there exist challenges which are not well documented. "Reference [7] proposes that adoption of agroforestry practices like any other innovation is a process influenced by a number of both physical and social factors".

This study identified influencing factors that include; gender of farmers, land size, level of education, farmers' experience, farmers' association, contact with research and extension, land tenure, agro-ecological zone, distance to nearest center, and farmer's income.

Agroforestry practices and knowledge are transmitted via traditional means; personal communication, impersonal documents e.g. mails and memos; extension agencies, face-to-face meetings, publicity events and demonstrations farms. According to reference [8], the $21^{\text {st }}$ Century saw 
emergency of modern communication pathways that range from simple to more rich and modern tools which use ICTs. Overall, these ICTs such as computers, GPS systems, mobile technologies, satellite radios, and TVs, World wide web in the agroforestry value chain to mention but a few, have expanded networking and transmission of complex electronic data, and bulky agricultural information to wide and diverse audiences [9], increasingly putting a premium on intellect and knowledge as the dominant factors of production. This is a major change that is reshaping the farming household's economy.

"Reference [10] argues that ICTs are relatively complex unless farmers using are educated to utilize these tools for acquiring information efficiently and cost-effectively". Similarly, in a people-centered participation approach of communication, identification of networks of information flow provides deeper insight into the pattern of information exchange in the farming community [11].

Adoption of agroforestry practices in Kenya is disadvantaged by adverse policies, legal constraints and lack of coordination between the governmental sectors to which it contributes; namely, agriculture, forestry, rural development, environment and trade. Aspiration of agriculture policies in Kenya since independence has generally has been to attain self-sufficient in basic food production for domestic consumption and export, generate farming incomes, expand strategies and levels of profitable and efficient food production. Buttoud [12] observe that agroforestry has not been addressed sufficiently in policy formulation, and nor has it been integrated into land-use planning or rural development programmes. Thus, the potential of agroforestry to enrich farming communities and national economies has not been fully exploited.

\subsection{Problem Statements}

Kenya's economy is heavily dependent on agriculture which on the other hand is the leading driver of deforestation [12]. Agricultural research institutions, universities and colleges, public and private agricultural based firms as well as financial institutions are the basis of policies that informs and guide farming decisions so as to impact positively on the desired farming goals.

Vision 2030 blue-print [13], a Government of Kenya's Policy document, prods a growing concern among farmers engaged in the tree growing and tree/crop inter-growing on-farm. This type of agroforestry system [14] shows many challenges that include limited access to information source and inadequate knowledge on tree/crop growing on-farms precisely in Arid and Semi-Arid Area (ASALs).

Few studies have been undertaken to investigate how information sources publicize information for adoption of agroforestry practices within farming communities. Most of this information is derived mostly from biophysics such as soil erosion control. Consequently, many farmers are poorly informed as they do not understand extension factors that lead to agroforestry practices. It is therefore of great concern that information, through ICT, on factors influencing adoption of agroforestry practices is insufficient and should be studied.

\subsection{Objective of the Study}

The broad aim of the study was to identify the ICT information sources used in the adoption of agroforestry practices and what factors influence the use of these information sources by smallholder agroforestry farmers in Kajiado Central, sub-County.

\subsection{Research Questions}

This study sought to answer the following questions:

1.3.1. Is there positive correlation relationship between the available ICT information sources and agroforestry practices among small-scale farmers?

1.3.2. Do socio-economic factors affect the farmers' access to sources of ICT information?

\section{Methodology}

\subsection{Study Area}

The study was carried out in Kajiado Central sub-County in the southern part of the Great Rift Valley. The sub-County covers about $21,105 \mathrm{Km}^{2}$. It is divided into five administrative divisions namely: Central, Bissil, Namanga, Elangata wuas and Ildamat [15]. The sub-County neighbours Mashuru to the East, Republic of Tanzania to the South West, Loitoktok sub-County to the South East, Makueni sub-County to the North East, Isinya sub-County to the North and Kajiado North sub-County to the North West.

About 50 per cent of the sub-County lies in semi-arid zones (zones AEZ-V, 37 per cent under AEZ-IV and 80 per cent under AEZ II-IV [16]. The rainfall pattern is bi-modal with long rains falling in between March and May and the short rains falls between October and December. The sub-County receives between 500 to $800 \mathrm{~mm}$ average annual rainfalls while maximum rainfall is estimated at $1,250 \mathrm{~mm}$ per annum. 


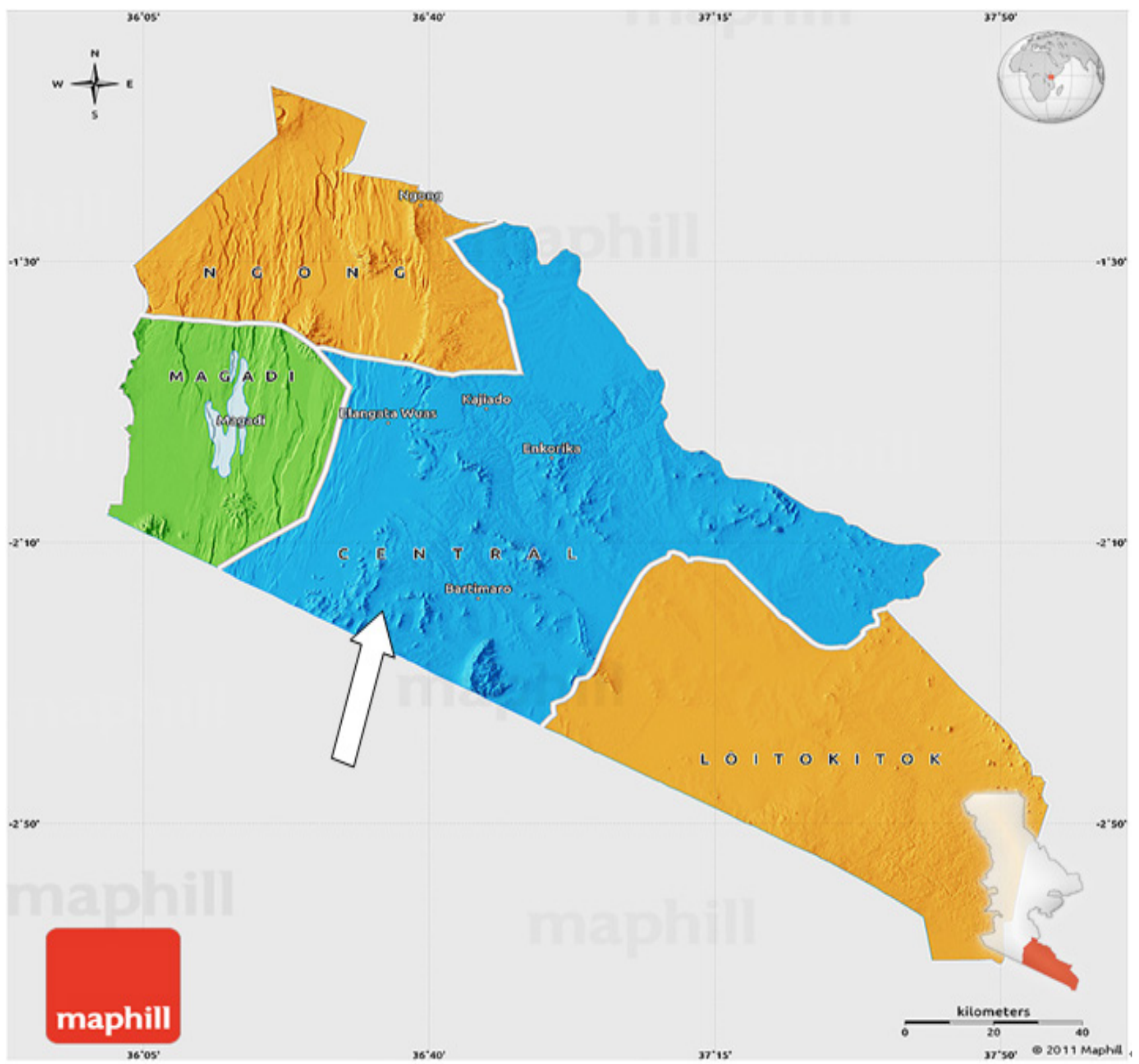

Figure 1. Map of Kajiado County with arrow showing the Central sub-County [17]

This sub-County was purposely selected for this study because it is one of the ASALs areas in Kenya where tree growing technologies were predicted to cascade during the implementation of Social Forestry Training Project (SFTP), a joint project formulated in 1987 between Kenya and Japan Governments [18]. Kitui and Makueni sub-Counties were the focal points where the project developed tree planting technologies to improve provision of forest products and the livelihoods of the inhabitants $[19,20]$. These sub-Counties experience erratic change in land use, dynamic agricultural and livestock productivity, low incomes and poverty [21]. Initially, majority of the land in Kajiado Central sub-County was communally owned by Maasai pastoralist who engaged largely in livestock production but lately the land is being subdivided into individual small farm holdings. The new land use arrangements coupled with social and economic changes has placed the community in a transition lifestyle
[22]. This new land system, aggravated by recurrent drought and other climatic changes presents distinctive problems to the farming community and the existing natural resources.

For instance, indigenous tree species that dominated the area, some conserved into fodder banks for use during dry spell are threatened by land degradation and human activities such as charcoal production, clearance for structures or conversion to agricultural uses. This diverse shift of farming system provided a good entry into the study.

\subsection{Research Design}

This study used a non-experimental research design where a survey [23] was conducted to measure responses from small-scale farming households practicing agroforestry within Kajiado Central sub-County. Munyua [24] defines small-scale farmers as growers that derive their livelihood 
from holdings of less than 2-5 acres (usually less than 2 hectares). Therefore most of the study respondents were smallholder farmers (98.2\%) having a farmland ranging between less than 1 and 3.5 hectares.

\subsection{Sampling and Sample Size}

Population for this study was 201 small-scale farming households registered by Kenya Forestry Service (KFS) in the sub-County. A sample size of 67 heads of households which was about $30 \%$ of smallholder farmers were selected using a using a simple random sampling method [25].

Snowball sampling method was used to select respondents who gave multiple referrals of whom only one subject was interviewed amongst them. These households are sparsely distributed within the sub-County whose population density is 22 per $\mathrm{Km}^{2}$. Thus, the choice of the new respondent was guided by factors such as social networks, accessibility and the level of farmer's willingness to respond.

\subsection{Data Collection and Analysis}

Primary data comprising respondents demographic attributes; age, gender, level of education, monthly income, and land size; socio-economic factors; and information sources sought by farmers was collected using semi and close-ended structured questionnaire. The questionnaire was pre-tested before administration between April and June 2014. Similarly, secondary data consisting of information from literature, and reports with relevant information was referred to.

Descriptive statistical analysis including frequency distribution, percentage, cross tabulation, mean and standard deviation (SD) were used for data analysis using Statistical Program for Social Scientists (SPSS) version.

Data was analyzed using descriptive statistics that involved the use of frequency distributions. Pearson Chi-square test $\left(\mathrm{X}^{2}\right)$ and regression analysis was used to test statistical significance (differences) between the farmers' socio-economic and specific characteristics variables and results presentation in tables, graphs and charts.

\section{Results and Discussions}

Results from this study show that the small scale farming households in the sub-County access agroforestry knowledge and practices from sources both ICTs communication channels [26]; such as mass media, with minimal use of social media and primary sources; research institutions, universities; Agricultural based firms and financial institutions as well as other secondary sources; farmers to farmers meeting, neighbours and extension agents, that are the most frequent used information sharing platforms.

\subsection{Information Sources}

The outcome of the respondents query on information sources and the reasons for interaction shows ICTs enabled knowledge exchange amongst the farming households thus increased farmers' awareness of information on agroforestry practices (Table 1). Of the respondents, $81.8 \%$ accesses mass media which include radio and television and $6.8 \%$ regard it credible. Extension agents, individual farmers are highly accessible with $87.8 \%$ and $81.8 \%$ respectively. Both research institutions and Universities are the least accessible but they offer credible and appropriate information. Test statistic show $p$-value is $<\alpha=0.005$ indicating an interaction between farming households and the listed information sources.

Table 1. Information sources and reasons for interaction

\begin{tabular}{|c|c|c|c|c|c|c|}
\hline \multirow{2}{*}{$\begin{array}{l}\text { Source of the } \\
\text { information }\end{array}$} & \multicolumn{6}{|c|}{ Reasons for interacting } \\
\hline & $\begin{array}{c}\text { Credibility } \\
(\%)\end{array}$ & $\begin{array}{c}\text { Appropriateness } \\
(\%)\end{array}$ & $\begin{array}{c}\text { Accessibility } \\
(\%)\end{array}$ & $\begin{array}{c}\text { Ease to use } \\
(\%)\end{array}$ & $\begin{array}{c}\text { Not sure } \\
(\%)\end{array}$ & $\begin{array}{l}\text { Total } \\
\text { (n) }\end{array}$ \\
\hline Universities & 57.1 & 28.6 & 2.0 & 0.0 & 12.2 & 49 \\
\hline Research institution & 30.6 & 57.1 & 0.0 & 0.0 & 12.2 & 49 \\
\hline Financial institutions & 20.0 & 2.2 & 20.0 & 4.4 & 53.3 & 45 \\
\hline Mass media & 6.8 & 0.0 & 81.8 & 6.8 & 4.5 & 44 \\
\hline $\begin{array}{c}\text { Agricultural based } \\
\text { firms }\end{array}$ & 6.1 & 30.6 & 57.1 & 0.0 & 6.1 & 49 \\
\hline Individual farmers & 4.1 & 6.1 & 87.8 & 2.0 & 0.0 & 49 \\
\hline Internet & 2.0 & 2.0 & 20.0 & 70.0 & 6.0 & 50 \\
\hline Extension agents & 0.0 & 2.1 & 93.6 & 2.1 & 2.1 & 47 \\
\hline
\end{tabular}




\subsection{Communication Channels}

Table 2 shows the frequency and \%age of secondary information sources that incorporate ICTs used to access information on agroforestry practices. Neighbours, friends and extension agents with average $53.7 \%$ respondents used face to face communication channels. On average $34.1 \%$ used ICTs namely radio, television, telephone and internet, and $28.8 \%$ on average relied on demonstration and publicity events.

Table 2. Frequency of Communication channels used in sharing agroforestry information

\begin{tabular}{|c|c|c|c|}
\hline Channel & Frequency & $\%$ & Total \\
\hline Neighbour and friends & 45 & 67.1 & 100 \\
\hline Group meetings & 40 & 59.7 & 100 \\
\hline Radio programmes & 39 & 58.2 & 100 \\
\hline $\begin{array}{c}\text { Agricultural publicity } \\
\text { events }\end{array}$ & 38 & 56.7 & 100 \\
\hline $\begin{array}{c}\text { Agricultural } \\
\text { publications/reports }\end{array}$ & 31 & 46.3 & 100 \\
\hline Extension agents & 23 & 34.3 & 100 \\
\hline Internet and blogs site & 20 & 29.8 & 100 \\
\hline $\begin{array}{c}\text { TV news and related } \\
\text { programs }\end{array}$ & 19 & 28.4 & 100 \\
\hline Research centers demos & 19 & 28.4 & 100 \\
\hline Telephone & 14 & 20.9 & 100 \\
\hline Church & 1 & 1.5 & 100 \\
\hline
\end{tabular}

\subsection{Communication Pathways Levels of Influence}

This study found ICTs, neighboring farmers, extension agent and group meetings were highly influential communication channels used by the households (Table 3 ). Since the $p$-value is less than $\alpha=0.05$ we conclude that there is statistical significance and the level of influence by the communication pathways is significant.

Table 3. Use of ICTs on adoption of Agroforestry practices from institutions

\begin{tabular}{|c|c|c|c|c|}
\hline \multirow{2}{*}{$\begin{array}{c}\text { Source of } \\
\text { Agro-forestry } \\
\text { information }\end{array}$} & \multicolumn{4}{|c|}{$\begin{array}{l}\text { Do you use ICTs devices while seeking agroforestry } \\
\text { information }\end{array}$} \\
\hline & Yes (\%) & No (\%) & Total (n) & $\begin{array}{l}\text { Total } \\
(\%)\end{array}$ \\
\hline $\begin{array}{l}\text { Research } \\
\text { Institutions }\end{array}$ & 81 & 19 & 26 & 100 \\
\hline Universities & 88 & 12 & 17 & 100 \\
\hline $\begin{array}{l}\text { Agricultural } \\
\text { business firms }\end{array}$ & 77 & 23 & 13 & 100 \\
\hline $\begin{array}{l}\text { Financial } \\
\text { Institutions }\end{array}$ & 100 & 0 & 1 & 100 \\
\hline
\end{tabular}

The result Chi-square value $\chi^{2}=0.932$, probability $p=.818$ $(\alpha=0.05)$ show relationship between the information sources and adoption of agroforestry practices within smallholder agroforestry households. This verifies tree planting on farm has impacted on the quality of life, since $84.2 \%$ of the respondents indicated they benefited with tree products e.g. fuelwood, herbal medicine, fruits, soil control, protection (fencing and shade), and aesthetic.

Regression analysis also show statistical significance between use of ICTs as sources of information and adoption of agro-forestry practices; that is, the adoption of agro-forestry practices is dependent on farmers' interaction with institutions.

This study established that farming households' socio-economic factors such as level of education, tenure of land, land size, net monthly income, and distance to the shopping centre affect farmers' access to information sources. A cross tabulation using Chi-square significant $(\alpha=0.05)$ shows a significant relationship between sources of agro forestry information and these socio-economic factors.

Contrary, there is no significant relationship between the type of house and period of settlement and access to information sources (Table 4). The Chi square formula used is as follows:

$$
\frac{(\text { Observed }- \text { Expected })^{2}}{\text { Expected }}
$$

Table 4. Relationship between socio-economic factors and access to information sources

\begin{tabular}{|c|c|c|c|}
\hline Socio economic factors & Chi-Square & df & $\begin{array}{c}\text { Asymp. Sig. } \\
(\mathrm{a}=0.05)\end{array}$ \\
\hline Level of education & $10.429^{\mathrm{a}}$ & 3 & .015 \\
\hline Type of house & $5.778^{\mathrm{a}}$ & 4 & .216 \\
\hline Tenure of land & $11.097^{\mathrm{a}}$ & 2 & .004 \\
\hline Period of settlement & $6.786^{\mathrm{a}}$ & 3 & .079 \\
\hline Land size (acreage) & $47.019^{\mathrm{a}}$ & 30 & .025 \\
\hline Net monthly income & $9.514^{\mathrm{a}}$ & 1 & .002 \\
\hline $\begin{array}{c}\text { Distance to the nearest } \\
\text { shopping centre }\end{array}$ & $10.827^{\mathrm{a}}$ & 4 & .029 \\
\hline $\begin{array}{c}\text { Other farming } \\
\text { practices/animal } \\
\text { husbandry }\end{array}$ & $26.782^{\mathrm{a}}$ & 12 & .008 \\
\hline
\end{tabular}

\section{Conclusions}

This study has revealed that social interactions between neighbouring farmers, contacts with extension agents and use of ICTs are essential in adoption of agroforestry practices. Integrated agroforestry systems are increasing on farms in the form of boundary marking, home gardens, woodlots, pasturelands and alleys cropping [27]. Results shows that adoption of agroforestry practices can be strengthened by promoting regular farmers-to-farmers dialogue as observed by Frenzel and Kiptot[28,29] who noted that farmers are the prime agents of change in their respective communities.

The socio-economic variables studied indicate they affect the farmer's decision to adopt agroforestry. For instance, low formal education $(21 \%)$ and poverty is a hindrance to 
adoption of agroforestry practices. Household heads above 49 years, who are mainly decision-makers, should be sensitized on the risks of deforestation, negative effects of climate change and the importance embracing farm forestry.

\section{Recommendations}

Reflecting on the findings of this study, agricultural institution should engage more in development of intervention as well as realistic strategies for disseminating and assessing technologies transfer. The change agents should improve their communication skills and avoid the use of excessive media or theoretical trainings which at times are ineffective to the intended audience.

The government working jointly with other development partners should; promote use of ICTs in agriculture and put in place pro-active policies to promote on-farm forestry; to mitigate the negative impacts of climate change; reduce the imbalance in the market of forest products such as timber, poles and posts and alleviate poverty [30]. Consequently, these policies should optimize awareness creation through multidisciplinary approaches that supports infrastructure and economic empowerment, and cascaded to the grass root level for ownership and implementation.

Finally, considering that data was captured from a sample of small farm holders and that some households declined to respond on matters of land and incomes, this made it impossible to draw a firm conclusion. Thus, further studies are recommended using a wider ecological unit of farming households and more so with household owning more acreage of land within the county to predict whether they follow the same pattern when adopting agroforestry practices.

\section{Acknowledgements}

Thanks to KEFRI management for providing funding to undertake this study. All the stakeholders at all levels in Kajiado County, including farmers, extension agents, officers, and enterprise owners for their unreserved cooperation and data provision during the survey time. Special thanks to Dr. Sabina Wangia and the late Dr. Fred Mugivane from University of Nairobi, department of agricultural economics for their supervision during this study, Drs. Jane W. Njuguna, Vincent Oeba and Jecinta Kimiti, and the two anonymous reviewers for valuable contributions that improved this manuscript. Mr. Paul Tuwei, Dr. Ebby Chagala-Odera and Ely Mwanza for logistic support and many more who helped during the field survey.

\section{REFERENCES}

[1] G. Onuekwusi and C. Gideon. 'Mass Media Agencies and
Information Programming for Agricultural Development in Imo, Nigeria'. Research Journal of Applied Sciences Vol. 2(2): 141-145, 2007.

[2] ICRAF, (World Agroforestry Centre). 'Annual Report 2011'. ICRAF, Nairobi, Kenya. 2011.

[3] S. Mohamed. 'A comparative analysis of pastoral economies: a case study of Mandera and Kajiado Districts, Kenya'. Egerton University, Kenya, 1998.

[4] C. Wambugu, S. Franzel, P. Tuwei, and G. Karanja. 'Scaling up the use of fodder shrubs in central Kenya'. Development in Practice 11(4): 487-494, 2001.

[5] C. Southgate, and D. Hulme. 'Environmental Management in Kenya's Arid and Semi-Arid Lands: An overview'. University of Manchester, 1996.

[6] R. Newell, and R. Stavins, 'Climate Change and Forest Sinks: Factors Affecting the Costs of Carbon Sequestration'. Journal of Environmental Economics and Management. Vol. 40, 3, Pages 211-235, 2000. Online available: http://www.jstor.org/stable/1388775.

[7] S. Kishor. 'The Influence of Household Economics and Farming Aspects on Adoption of Traditional Agroforestry in Western Himalaya' Division of Agroforestry, Sher-e-Kashmir University of Agricultural Sciences and Technology, Chatha, India, 2006.

[8] A. Twinomugisha. How Information Communication Technology (ICT) is transforming Africa; New Analysis and Tools for business Africa; African Business Source, 2009. Online: http://www.africabusinesssource.com, cited on 20th May 2011.

[9] A. Okyere, and D. Mekonnen, 'The Importance of ICTs in the Provision of Information for Improving Agricultural Productivity and Rural Incomes in Africa'. (IFPRI), Addis Ababa. UNDP. WP 2012-015, 2012.

[10] S. Adolwa, P. Okoth. R. Mulwa, A. Esilaba, F. Mairura, and E. Nambiro. 'Analysis of communication and dissemination channels influencing the adoption of integrated soil fertility management in Western Kenya'. The Journal of Agricultural Education and Extension, 18:1, 71-86, 2012.

[11] M. Hossain. 'Agricultural Technology and Development Communication Networking Patterns in Differentially Developed Villages of Bangladesh'. Journal of Sustainable Agriculture. Vol.12, Issue No.1, 57-80, 1998.

[12] G. Buttoud, O. Ajayi, G. Detlefsen, F. Place and E. Torquebiau. 'Agroforestry Working Paper no. 1. Agroforestry for Biodiversity and Ecosystem Services - Science and Practice', FAO, Rome. p 37, 2013.

[13] GoK, Policy Brief. 'A Publication of the National Coordinating Agency for Population and Development, No.14', Government Printer, Nairobi, Kenya, 2010. Online available: https://www.vision2030.go.ke/index.php/vision

[14] M. Kanyeki. 'Agroforestry practices, challenges and sustainability in Africa'. Melbone University, 2009.

[15] GoK, (2009). 'Kenya Population and Housing and Census Report vol. IA, II'. Kenya National Bureau of Statistics, Government Printer, Nairobi, Kenya, 2009.

[16] Jaetzold and Schimdt. 'Farming Management Handbook of 
Kenya, Volume 1-3'. Ministry of Agriculture, Nairobi, Kenya, 1983.

[17] Map of Kajiado Central sub-County. Online available on: http://www. Maphill.com (2014)

[18] Kenya Forestry Research Institute (2004). 'KEFRI Strategic Plan 2004'. Nairobi, Kenya Online available. http://www.kef ri.org.

[19] J. Cheboiwo, C. Osore and I. Miyagi. 'Species and provenance selection for afforestation in Kitui, 2nd National Social Forestry Conference', KEFRI - Nairobi, Kenya 6 to 9 October 2009.

[20] B. Kigomo. 'Restoring the Vegetation and Improving the Livelihoods of the Kamba and Maasai People in Kenya, in rehabilitation of degraded lands in drylands of Africa', 2001. Online available: http//:www.sswm.info/...attachments/MAD RELL\%20AND\%20BOWN..

[21] GoK 2005, 'District Development Plan, Kajiado District Strategic Development Plan 2005-2010', Government Printer, Nairobi, Kenya, 2005.

[22] T. Ochuodho, 'Participatory Development for Sustainable Management of Dryland Woodlands of Elang'ata Wuas, Kajiado, Kenya'. Proceedings of the Regional Social Forestry Extension Seminar for Semi- arid lands, 24-27 0ct. 2001, Pp $68,2001$.

[23] O. Mugenda and A. Mugenda, A. G. 'Research Methods: Quantitative \& Qualitative Approaches'. Nairobi: Press
African Center for Technology Studies (ACTS), 2003.

[24] H. Munyua, E. Adera, and M. Jensen. 'Emerging ICTs and their Potential in Revitalizing Small-Scale Agriculture in Africa'. A paper presented at the World Conference on Agricultural Information and IT (IAALD/ AFITA/WCCA), Tokyo, Japan, 23-27 August, 2008.

[25] W. Cochran. 'Sampling Techniques (3rd Edition)'. John Wiley \& Sons. Library of Congress, 1977.

[26] M. Tucker and T. Napier, 'Preferred Sources and Channels of Soil and Water Conservation Information Among Farmers in Three Mid-Western US Watersheds'. Agriculture. Ecosystems and Environment Journal, Vol. 92, 297-313, 2002.

[27] C. Wambugu, S. Franzel, P. Tuwei and G. Karanja. 'Scaling up the Use of Fodder Shrubs in Central Kenya'. Development in Practice Vol. 11(4), 487-494. 2001.

[28] S. Franzel. 'Socio-economic factors affecting the adoption potential of improved tree fallows in Africa'. Agroforestry systems Journal, Vol. 47 (1-3), 305-321, 1999.

[29] E. Kiptot, S. Franzel, P. Hebinck and P. Richards. 'Sharing seed and knowledge: Farmer-to-Farmer dissemination of agroforestry technologies in Western Kenya'. Agroforestry Systems Vol. 68: 167-179, 2006.

[30] J. Pretty. 'Regenerating agriculture: policies and practice for sustainability and self-reliance', Earthscan publications Limited, London, pp 26, 1995. 